Copyright of Full Text rests with the original copyright owner and, except as permitted under the Copyright Act 1968, copying this copyright material is prohibited without the permission of the owner or its exclusive licensee or agent or by way of a licence from Copyright Agency Limited. For information about such licences contact Copyright Agency Limited on (02) 93947600 (ph) or (02) 93947601 (fax)

\title{
All our Christmases come at once: war, peace and the fin de siècle
}

\author{
Heather Scutter
}

$\coprod \mathrm{n}$ $\mathrm{n}$ the first paragraph of the first chapter of her Sexual Anarchy: Gender and Culture at the Fin de Siècle, Elaine Showalter quotes the novelist Angela Carter: 'the fin is coming a little early this siècle' (Showalter 1991, p.1). It is an aspect of this premature ejaculation into rehearsing the rites and values of end of cycle thinking and practices that we also, in western culture, prematurely rehearse and celebrate other ritual events, specifically that of Christmas. It used to be that Christmas began on the $25^{\text {th }}$ of December: that is the first day of Christmas, leading up to Twelfth Night and the Feast of the Epiphany on January 6. But we, in neurotic modern times, begin weeks too early, and are so frazzled by the time we get to the day itself that we lose the proper freshness of the season. As one journalist puts it:

Nowadays, by the time your true love turns up with the swans a-swimming and drummers drumming, you are back in a power suit at your workstation doing the August cashflow forecasts, having forgotten all about the birth of Jesus. The lords a-leaping are totally frozen out, and have to leap right out the door again and console themselves with Easter eggs (already in the shops. naturally. just down the aisle from the new season's swimwear).

(Purves 1999, p.9)

The anxious enervation of our culture is marked not only by early rehearsal of ends of cycles, and of cultural rituals such as Christmas and Easter, but also of the end of childhood, the movement from childhood to adolescence and young adulthood. Having lost strong metanarratives that support and inform our cultural practices, we clutch fearfully to the forms and the structures, hoping that value-adding will come by the way: such behaviour magically invokes an end result. Our sense of an ending is thus dependent upon doubtful beginnings and recycled and unreliable middles. Little wonder, then, that with our rational disbelief in our helpless leaps of faith, our narratives have begun to turn in upon themselves, as if parodically, yet without satiric intent - hollow narratives through which the wind whistles as through dry grass.

Ends of cycles predicate a strong reversion to mythical thinking and behaviour, whether that cycle end a year, a century or a millennium. The fin de siècle has been characterised not only by transformative millennialism but also, and more usually, by enervation and impotence. I have long been fascinated with representations of Christmas in children's literature and, even though it may seem cross-grained to take up a subject so laden with power and hope in relation to the fin de siècle, examination of a range of historic and cultural examples proves illuminating. While the antecedents of Christmas, the pagan sun-return festivals, are associated primarily with the ritual turn of the year from frozen midwinter to the promise of spring and the rebirth of green out of the wasteland, Christmas specifically promises forgiveness and eternal life through the birth of the Christ child, given by God the father to take on, in the mythic manner of the pharmakos figure, the sins and burdens of humanity. The mythic message is of peace and goodwill toward men. In many children's books of this century, the mythos of Christmas forms a motif which sets a particular kind of child, family, nation and culture against mythoi of war.

The Christmas chapter in Laura Ingalls Wilder's Little House on the Prairie (1932) looks back to a celebration of spartan non-self-indulgent pleasures within the context of the tiniest possible community - the nuclear family plus Mr Edwards - but it is only a brief episode, framed by the intimidating visit of the tall Indians on one side and, on the other, by the chapter of the panther's scream in the night and then by the chapter of the Indian jamboree, threatening in another way because, according to $\mathrm{Pa}$, the government intends to make the Indians move on out of white-settled territory. Such a Christmas, whilst reinforcing Puritan values of simplicity and frugality, also sets the white culture in miniature as surrounded by aggressive and proprietorial otherness.

The Christmas of the Wilders is both austere- 'Think of having a cup and a cake and a stick of candy and a penny. There had never been such a Christmas' (p.155) - and secular. The family, with the child at the centre, is sanctified. The whole scene is bathed in nostalgic retrospection: that of Wilder as narrator remembering a simple, happy Christmas long gone; and that of $\mathrm{Ma}$ and $\mathrm{Pa}$, who reflect on 'Christmas times back in Tennessee and up north in the Big Woods' (p.156). And yet I detect a note of anxiety in the determined need to demonstrate 
the superiority of the family Christmas to the lonely bachelor and surrogate Santa Claus, Mr Edwards.

Rumer Godden's The Dolls' House (1947) depicts a domestic war created at Christmas when the present of a new-old doll, Marchpane, creates chaos and seeds envy in the blended family resident in the dolls' house. The war here is one of class and security of tenure, the right to belong to a particular territory. The carols sung, of mastery and of peace and goodwill, ironically speak against each other, and a terrible sacrifice is enacted. At first it seems that Christmas has brought peace and joy, and all the wishes Tottie has made for the disparate dolls:

The voices brought Christmas into the dolls' house. "Can such a large thing as Christmas be in a dolls' house?" asked Mr Plantaganet. "It is so large. See, it has spread over the whole world. and for so many years, nearly two thousand years," said Mr Plantaganet, the dark brown of his eyes looking large too. "Howlarge it is, "said Mr Plantaganet.

"It is beautifully small too," said Tottie. "Perfectly small."

... When you have lived as long as Tottie, you will learn that small things are not as small as they seem, nor large things as large; nothing is small and nothing is large when you have become accustomed to the world.

(p.92)

But, at the mythic turn of the year, evil can gain entry and despoil paradise. Immediately post-WWII, this text is perhaps the most disturbing of all considered in this paper, for the atmosphere is so bitter and competitive, so hostile and poisonous, at Christmas time. What is left is the notion of a reconfigured and bereft family and a sense of fractured generations. It is not the child which gives hope in this text but the very old Tottie, the wooden peg doll who has endured through generations of callous and thoughtless childhoods.

C.S. Lewis's The Lion, the Witch and the Wardrobe (1950), again very close to that apocalyptic war, represents a cosmic war between the forces of good and evil, and uses the figure of Father Christmas iconically to set up the possibility of its being winter forever, 'always winter and never Christmas' (p.23). Narnia, when the children first enter it, is paralysed by perpetual whiteness: it is only when Father Christmas appears that there is the possibility of movement, of liquidity, of resistance to the thrall of the white witch:

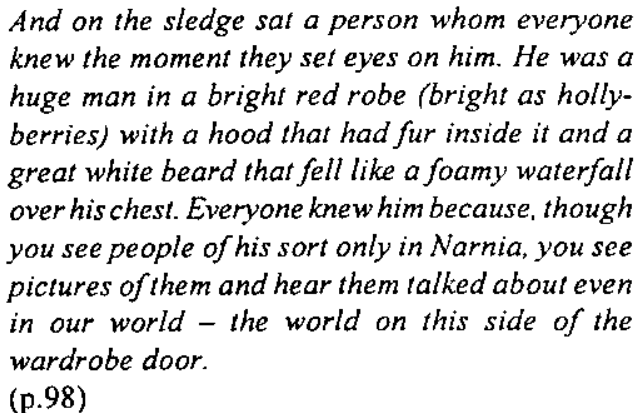

He is an anticipation of Aslan himself, and inspires a similar awe that renders the children 'very glad, but also solemn' (p.99). It is he who gives presents ('tools not toys', p.99) resembling magical gifts from the gods to the children a sword and shield to Peter, a bow, arrows and ivory horn to Susan, and a bottle of cordial and dagger to Lucy. He heralds the retum of Aslan, the Christ figure, whose bloodsacrifice and glorious retum enable the return to life of all Namia. The hideous battle in which Aslan's forces are triumphant acquires its power through that enabling image of Father Christmas who, after all, provides much more substantial feasting than the Turkish delight peddled by the witch. Lewis's text, set during the second world war, and written just after it, uses Christmas for its mythic resonance but, like the earlier texts, makes much of the militaristic forging of peace through war. And, significantly, it conjoins emblems of Christmas and Easter, with Aslan's death and resurrection. In its movement from Christmas to Easter. The Lion, the Witch and the Wardrobe is definitively a text about discarding childhood and growing up, assuming mature knowledge and responsibilities. The transcendental family of Namia is sanctified, in particular through its successful waging of a holy war.

Lucy Boston's The Children of Green Knowe (1954) takes not a family of children separated from their parents during the war but a single child effectively orphaned by the colonial service of his father and his remarriage to an unsympathetic stepmother figure. Boston islands the castle 
that becomes Tolly's home, inserts him in a horizontally sparse but vertically enriched family (with his greatgrandmother Mrs Oldknowe and all those ghost children from three centuries before), and then, when he has a sense of territory and belonging rich in mythic meanings, she allows attack by the alien forces of the cursed Green Noah figure. The war here becomes a natural one, and Tolly, naturally, wins and inherits the kingdom. Notably the Christmas acclaimed sidesteps near history and recuperates medieval practices, customs and structures:

When they had finished decorating it, the old room looked more like the Knights' Hall than ever. Against the stone walls, on top of the stone chimney-piece, the dark green leaves themselves looked medieval. It was an ancient castle prepared for an ancient feast. (p.131)

The real enemies are clearly to do with class transgressions. The story's battle takes place a couple of days before Christmas proper, at the midwinter solstice and true turn of the year, when ghosties can gain entry through strange spaces. Christmas is established in old religious terms (the modern church, with its dinginess, rush matting and electric light, is dismissed in favour of the medieval version, with its gentle candle light, wide stone spaces and exquisite singing). All of the modern rituals are refracted in terms of the very very old, drawn backwards into a tiptilted telescope of memory. Family is reduced, rendered quintessential, feminised and protected by special mythic forces. Time and place become synonymous and interchangeable.

There is a strong sense, as in Lewis's novel, of Christian Platonism: on Christmas Day, Tolly loves all his treasures but it is 'their shadows that he loved perhaps even more' (p.157). Between the shadow and the reality, I would contend, there is a gap that speaks not only of the embattled recuperation of Englishness after WWII, but also of space and property under siege from other classes and wandering peoples (the gypsies), and of feminine ownership of the home replacing the failed and/or absent masculine. The potential of the present child inheres solely in his capacity as a chosen vessel for past purity of memory.

Russell Hoban's The Mouse and His Child (1967) moves further from the sacred to the secular and sanctifies paternity rather than maternity. The loving God who breathes life into humans is replaced by a tramp who sets the metal windups going when they outlast their function as Christmas toys and decorations, disappears when their quest becomes tough, and reappears to bless them after they've done all the hard work and achieved self-winding. In this text, the child makes all questing meaningful: without him, there would be no reason to go forward, no recognition of lack and no desire. While rituals are evacuated of traditional meaning, this meaning, made over, is reinserted at the end. After the wasteland of the dump, after the frozen paralysis of midwinter and the fisher king/kingfisher, after the re-establishment of a newly blended family and a re-collection of all the old members, including Manny Rat, a Lucifer-Scrooge figure converted and rendered harmless, the bluejay reports 'Seasons greetings, feelings of intense good will expressed by all' (p. 186). The Darwinian wars of the shrews and owls, the wars of attrition of the dump overlords, pale into insignificance: right and might miraculously and poignantly converge in the image of the house of all nations welcoming all comers at Christmas time. Whilst more than three decades ago there are all the fin de siècle characteristics of urbari decay, environmental pollution, family breakdown, social corruption and even species transgression, there is yet allowed a still small voice of transcendence. Christmas frames the action, emptied albeit of religious portent but transformed rather into both universalised and secularised spiritual meanings: all the way from existential tramping to sanctified and ragged home, territory and family with a remarkable padonna and child:

The tramp saw father and son with their family and friends about them. He saw The Last Visible Dog in all the brightness of its lights against the night; he heard the singing and the merriment inside; and he smiled and spoke to the mouse and his child for the second time.

$$
\text { (p.186) }
$$$$
\text { "Be happy," said the tramp. }
$$

In Nina Bawden's Carrie's War (1973), in which the children Carrie and Nick, as evacuees in the Welsh valley, are insulated from the real adult war, but are exposed instead to all the factors that produce war on a broader scale - territorial possession, jealousy, repression 
- there is a kind of rewriting of Dickens's $A$ Christmas Carol as a 'culture text' (Davis, 1990, Chapter One). Mr Evans is a Scrooge figure only partially converted: the children receive scant presents (a penknife for Nick, a Bible for Carrie), and scant food. The Methodist Calvinism of the Evanses is contrasted with the true Christmas, and feasting, that the children have received a few days before, near the winter solstice, at Hepzibah's kitchen in the Druidic grove. The present appears cold and loveless when contrasted with this feminised recuperated pagan past, where plenty of food and plenty of love are conflated. In this 'queer place', 'full of the old religion still', Hepzibah's kitchen offers absolute sanctuary:

A warm, safe lighted place. Hepzibah's kitchen was always like that, and not only that evening. Coming into it was like coming home on a bitter cold day to a bright leaping fire. It was like the smell of bacon when you were hungry; loving arms when you were lonely; safety when you were scared ...

(p.46)

It also offers, along with a huge plate of mince pies, and Welsh milk, ham, bread and butter, an authentic Gothic Christmas story in the shape of Hepzibah's tale of the 'screaming skull'.

Ironically, such apparent absolute sanctity is not proof against familial war, and Carrie within a week finds herself acting as go-between and spy, despoiling her refuge. Ironically again, when Carrie returns thirty years later, it is to a kind of resurrection and Christmas all in one. While the big house has burnt down, the stables have been saved. And living in the stables Carrie finds her old madonna and holy child - the simpleton Johnny Gotobed.

Katherine Paterson's Bridge to Terabithio (1977) is another text in which Christmas and Easter are yoked in a rite of passage. Jesse wants desperately to give Leslie a miniature Japanese television set for Christmas, for he perceives her lack in this respect and wants to fill the cultural gap. Prince Terrien the puppy becomes the gift instead, one which accompanies them joyfully into Terabithia. Such life and simplicity are contrasted with the greedy consumerism of Jesse's older sisters, which is also gaudily on show at Easter, when the family attends church for the one time of the year, accompanied by
Leslie. She finds the Easter story, of death and resurrection. wonderful because she doesn't have to believe in it. Little wonder, then, that without the due dread and fear, with a reckless leap of faith over the flooded river, Leslie becomes the narrative's sacrificial lamb - albeit with the possibility of rebirth. God don't send any little girls to Hell, but it's a warning nevertheless.

Gillian Rubinstein's Beyond the Labyrinth (1988) could almost be about a character beyond childhood. Brenton's overwhelming sense of impending terrestrial apocalypse invalidates for him his family's fragile and brittle celebrations of Christmas, which are further rendered absurd by their being transposed to the southern hemisphere, where they coincide with midsummer rather than midwinter. Christmas takes up most of the action of this book, setting a mythicised meaning against a depleted culture ruled by consumerism, false gods and disintegrating families. Brenton is almost a Scrooge figure, opting out of buying presents, except for himself.

"I think I might duck out of Christmas this year!"

"Don't be silly!" Chris is not sure if it is a joke or not. "You can't duck out of Christmas. You always enjoy it anyway."

"You want everyone to enjoy it," he points out, "because it is your great production. Brilliant food, brilliant decorations, brilliant family life ... You more or less force everyone to enjoy it. And all that happens is that Dad drinks too much, and nobody really likes their presents, and it all costs too much money, and you end up crying."

He looks moodily out of the window as the sink fills with water. The lavender haze is there again, reminding him of another aspect of Christmas that gets up his nose. "Peace and goodwill to all men," he says disgustedly. "What a bloody lie!"

(p.52)

The alien Cal is in some ways a child and a Christ figure - she is small, and she is sheltered in the Trethewans' barn by the animals' hay; further, she is represented jokily as having come from a galaxy light years away, "bringing a message of peace and hope for the human race' (p.37). She is really from the earth of the future sacrificed to modern western culture, so that Easter and 
Christmas come perilously close to each other, wiping out the miraculous sense of everlasting future promised by the former and underscoring the terror of the latter, given that there is only a slender possibility of rebirth. For Brenton, the promise of peace on earth almost remains a 'bloody lie': myth is deposed as truth, reduced to a cultural falsity, a narrative told and told again to reinforce illusions. Even Vicky finds it difficult to read the meaning of the symbols:

Vicky stands in the family room for afew moments
watching the Christmas tree lights flash off and
on. They look as though they may be full of
meaning, like one of Cal's coloured patterns, but
she can't decipher what it is, so she decides she
may as well go to bed.
(p.92)

The novel's alternative endings offer only speculative glimpses of possible futures but the second does emphasise rebirth, green regeneration out of an exhausted and apparently sterile earth.

More recently again, Sonya Hartnett's Sleeping Dogs (1995) reeks of fin de siècle preoccupation with transgression, implosion, enervation. Griffin, the Godfather at the centre of the solipsistic, almost autistic world of the Willow family, has been damaged by his Vietnam war service and now has withdrawn to construct and live out his own bizarre customs, rituals and beliefs. Oxymoronically, he anticipates the 'years of tradition flying before him' (p.102). These customs, however, are weak parodies of the ruling cultural practices: when, on Christmas Day, the family gathers for its 'traditional' fox hunt - which on this particular occasion has as its victim the intruder figure, Bow Fox, who has threatened exposure of familial incest - the smell of European rituals is strong. Even more so than in Rubinstein's text, the motifs of Christmas and Easter, of birth and crucifixion, are dragged reductively together, insisting on the near-death of spirituality. I say near-death because there is still some differentiation between pharmakos figures: the grubby commercial artist Fox survives, but Jordan, the pure simpleton artist who is the closest the novel comes to a child figure, is shot in the comfield by his own father. This grotesque inversion of Christmas motifs signals the death of the faux holy child and, portentously, the death of childhood. War, peace and Christmas are conjoined in this young adult novel in pathologically involuted fashion. Its fin de siècle decadence inheres not in its gestures towards nihilism but in its self-conscious attempts to aestheticise meaninglessness meaningfully.

It has been argued that 'retellings of traditional story are especially apt not just to preserve culture but to reproduce conservative outcomes because of their shared outcomes about the functions of story and about what constitutes significant human experience' and that such retellings also say much about the ideologies of the 'cultural moment' (Stephens and McCallum, 1998, p.ix). While a historic shift in representations of Christmas, war and peace can be descried, there is no simple telos to be found. In some ways, the children's books written soon after World War II speak just as much as contemporary books of the fin de siècle, with their cosmic mythicising, their sense of apocalypse, their anxious attempts to recuperate threatened cultural values. End of century attempts to evacuate myth of significance lead, more often than not, to other kinds of myth-making which echo the ur-narratives thinly, autistically, perversely.

The movement from Christmas to an Easter whose crucifixion is absolute, without the hope or possibility of a resurrection, is paralleled by the movement of such fiction's concerns from the promise of childhood to the blasted heath of adulthood. To return to my earlier comments regarding hollow narratives through which the wind rustles as through dry grass, I conclude by arguing that childhood is in danger of becoming another hollow narrative, when retellings become not so much subversive, or even subversively conservative, but deeply reactionary.

Ian McEwan's adult novel, The Child in Time (1988), already a contemporary classic, is a narrative about a lost child and the loss of childhood. Stephen Lewis, a children's book writer, loses his daughter Kate in a supermarket one afternoon. She is lost utterly and irtevocably, abducted never to be seen again. Running parallel with this plot are images of childhood lost, in British and Western culture in general and, in particular, in the confronting subject matter of Stephen's radical new children's book, Lemonade. Here Charles Darke, Stephen's publisher, 
congratulates him on its groundbreaking representation and exposé of 'the child in time'; fascinatingly, he uses Christmas as both a historic and mythic marker:

Stephen, talk to a ten-year-old in midsummer about Christmas. You could be talking to an adolescent about his retirement plans, his pension. For children, childhood is timeless. It's always the present. Everything is in the present tense ... Reading you, they get wind of the idea that they are finite as children. Instead of just being told, they really understand that it won't last, it can't last, that sooner or later they're finished, done for, that their childhood is not forever. You put over to them something shocking about grownups, about those who have ceased to be children. Something dried up, powerless, a boredom, a taking for granted. They understand from you that it's all heading for them, as certain as Christmas.'

(p.33)

How significant it is that thenovel elides Christmas altogether because the child is lost, the family is broken, there can be no celebration. In a narrative complexly negotiating discourses of the lost/kidnapped child (Kate), lost childhood (western culture), sociologically engineered and fake childhood (the Government manual), a retum to childhood and death (Charles Darke), and regression to childhood and madness (Stephen's month of madness sucking Scotch), the seasonal highpoints are midsummer (impregnation) and the beginning of spring (birth, hope, a new child). It is a strange cultural phenomenon when the stories we tell children are more desolate than those we tell adults.

\section{REFERENCES}

Bawden, Nina $(1973 ; 1987)$ Carrie's War. Harmondsworth, Puffin.

Boston, Lucy $(1954 ; 1987)$ The Children of Green Knowe. Harmondsworth, Puffin.

Davis, Paul (1990) The Life and Times of Ebenezer Scrooge. New Haven and London, Yale UP. See especially Chapter One, 'The Carol as a culture text'.

Dickens. Charles $(1843$; 1988) A Christmas Carol. In Christmas Books, Oxford, Oxford UP.
Godden, Rumer $(1947$; 1972) The Dolls' House. Harmondsworth, Puffin.

Hartnett, Sonya (1995) Sleeping Dogs. Melbourne, Viking.

Hoban, Russell $(1967 ; 1976)$ The Mouse and His Child. Harmondsworth, Puffin.

Lewis, C.S. $(1950 ; 1967)$ The Lion, the Witch and the Wardrobe. Harmondsworth, Puffin.

McEwan, Ian (1988) The Child in Time. London, Picador.

Paterson, Katherine $(1977 ; 1980)$ Bridge to Terabithia. Harmondsworth, Puffin

Purves, Libby (Christmas/New Year 1999) 'Speaking personally', Woman and Home, p.9.

Rubinstein, Gillian (1988; 1990) Beyond the Labyrinth. Melbourne, Puffin

Showalter, Elaine (1991) Sexual Anarchy: Gender and Culture at the Fin de Siècle. New York, Penguin.

Stephens, John and Robyn McCallum (1998) Retelling Stories, Framing Culture: Traditional Story and Metanarratives in Children's Literature. New York and London, Garland.

Wilder, Laura Ingalls $(1932 ; 1993)$ Little House on the Prairie. London, Mammoth.

\section{NOTE}

This paper was delivered at the Children's Literature and the Fin de Siecle Conference, joint conference of the ChLA and IRSCL, Calgary, Canada, 5-9 July, 1999.

\section{BIOGRAPHICAL NOTE}

Heather Scutter teaches children's literature and nineteenth-century studies at Monash University. She has published many scholarly articles, and frequently reviews children's books in professional journals and newspapers. She is the author of Displaced Fictions: Contemporary Australian Books for Teenagers and Young Adults (Melbourne UP, 1999).

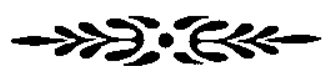

